\title{
ПРО ДІЯЛЬНІСТЬ НАЦІОНАЛЬНОЇ АКАДЕМІЇ ПЕДАГОГІЧНИХ НАУК УКРӒ̈НИ У 2020 РОЦІ ТА ЗАВДАННЯ НА 2021 PІК
}

Наукова доповідь на загальних зборах НАПН України 9 квітня 2021 р. https://doi.org/10.37472/2707-305X-2021-3-1-1-1

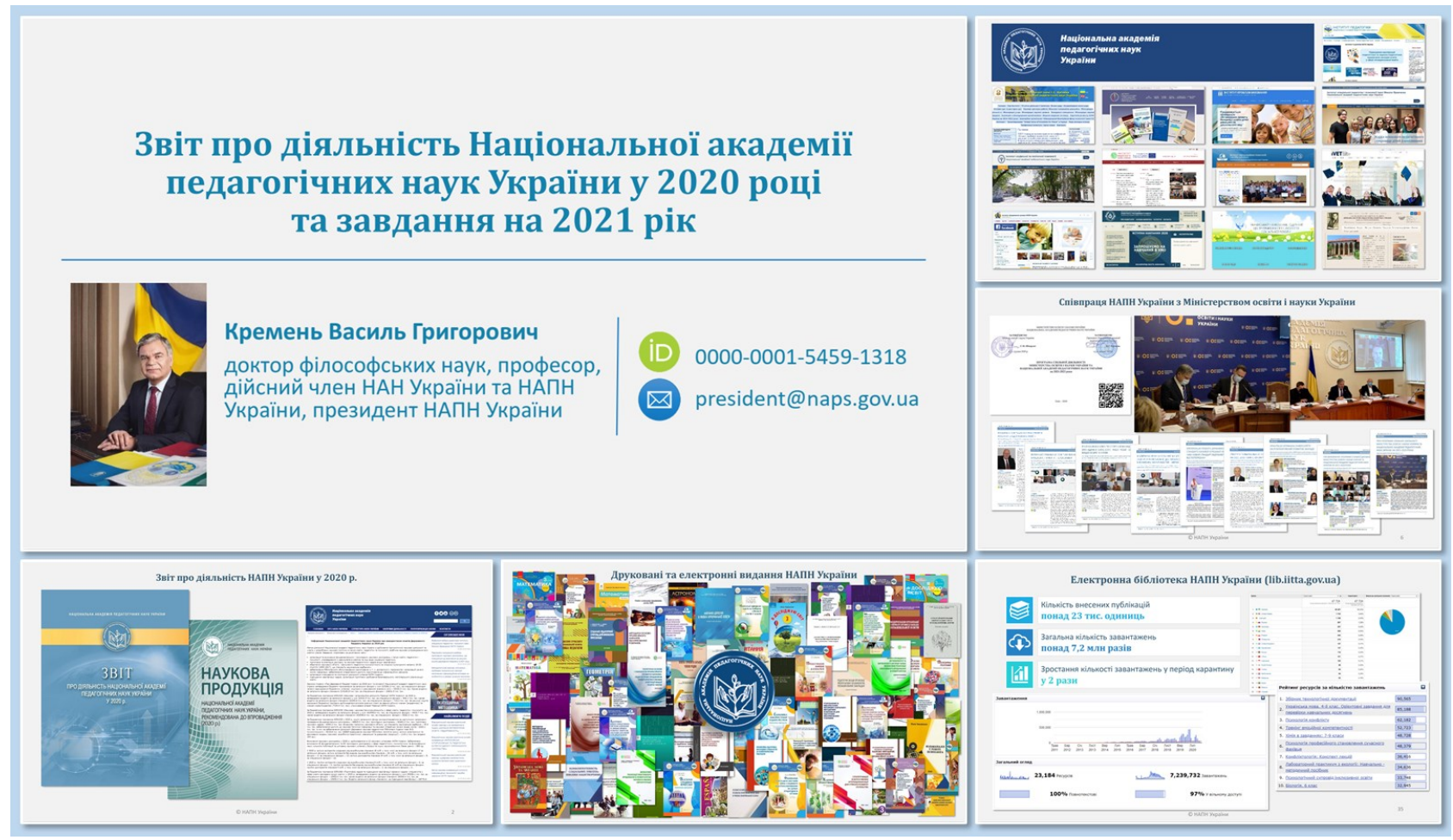

\section{KPEMEHb}

\section{Василь Григорович}

доктор фрілософських наук, профресор, дійсний член (академік) НАН України і НАПН України, президент Начіональної академії педагогічних наук України, м. Київ, Україна

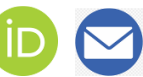

Анотація. Представлено діяльність Національної академії педагогічних наук України у 2020 р., що відповідно до пріоритетів державної освітньонаукової політики, визначених стратегічними і програмними документами, спрямовувалася на теоретико-методологічне й науково-методичне забезпечення функціонування та розвитку національної системи освіти, виконання статутних завдань загалом. Висвітлено результати роботи академії, ії підвідомчих установ, колективів вчених, дійсних членів і членівкореспондентів. Наведено найвагоміші наукові здобутки вчених академії за результатами виконання фундаментальних і прикладних досліджень та їх соціальний ефект упровадження. Розкрито роботу загальних зборів і методологічних семінарів, а також Президії НАПН України. Усебічно відображено експериментальну, видавничу, науково-організаційну, науковоекспертну, освітню, міжнародну, науково-інформаційну діяльність, співпрацю з органами державної влади і науковими організаціями, представлення наукових періодичних видань та публікацій вчених у світовій системі наукових комунікацій, проведення науково-практичних масових заходів, а також фінансове забезпечення.

Ключові слова: Національна академія педагогічних наук України; наукова діяльність; освіта України; педагогіка; психологія; науково-методичний супровід; інноваційна людина. 
Шановні учасники зборів!

Повний текст Звіту про діяльність Національної академії педагогічних наук України у 2020 р., розглянутого і схваленого Президією НАПН України 7 квітня 2021 р., розміщено на вебсайті НАПН України та в Електронній бібліотеці НАПН України. Також на вебсайті оприлюднено Інформацію НАПН України про використання коштів Державного бюджету України за 2020 рік та Наукову продукцію НАПН України за 2020 рік, рекомендовану для впровадження.

Крім того, ключові результати діяльності НАПН України у 2020 р. доповідалися на засіданні Національної ради України з питань розвитку науки і технологій 12 січня та на партнерському форумі «Освіта України 2021: стратегічні цілі та пріоритетні напрями» за участі глави держави В.О. Зеленського 9 лютого ц. р., що висвітлено у Віснику НАПН України за 2021 рік (Кремень, 2021a; Кремень, 2021b).

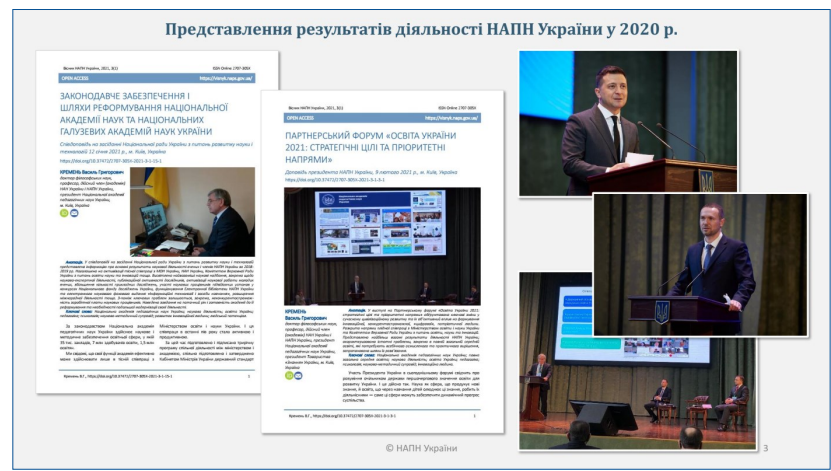

у зв'язку з цим у доповіді викладено найважливіші аспекти і результати діяльності НАПН України, їі Президії, відділень та підвідомчих установ у 2020 р. та завдання академічного колективу на 2021 рік.

Діяльність НАПН України у 2020 р. проходила в умовах непростих внутрішніх і зовнішніх викликів, що постали перед країною.

Насамперед це пандемія COVID-19 і збройна агресія Росії, тотальна цифровізація суспільного життя, прискорена пандемією коронавірусу, і посилення конкуренції країн і регіонів в умовах інноваційного типу прогресу, екологічна, кліматична небезпека планети і пов'язані з цим проблеми стійкого розвитку. Це робить ще більш актуальним зміцнення єдності української нації, здатної ефективно протистояти негараздам, відновити територіальну цілісність країни, увійти в русло стійкого соціально-економічного розвитку, реалізації конституційних норм щодо європейської та євроатлантичної інтеграції. Пошук відповідей

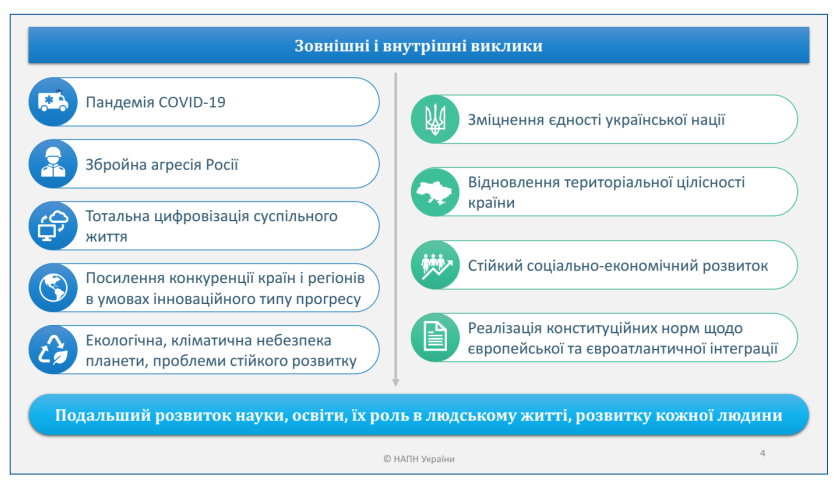

на ці та інші виклики вимагав подальшого розвитку науки, освіти, їх ролі в людському житті, розвитку кожної людини.

3 огляду на зазначене НАПН України у 2020 р. властивими їй методами наукових досліджень в освіті, педагогіці і психології, наукового і методичного забезпечення освітньої сфери системно своєчасно реагувала на суспільні виклики.

Треба зазначити, що системне перезавантаження влади, розпочате у 2019 р. в Україні, сприяло подальшому розкриттю і реалізації наукового і методичного потенціалу НАПН України та його більш ефективному використанню для модернізації освіти і науки, українського суспільства в цілому та його головного суб'єкта людини.

у 2020 р. успішно завершено виконання Програми спільної діяльності Міністерства освіти і науки України та Національної академії педагогічних наук України на 2017-2020рр. (Кремень та ін., 2020а) та затверджено нову Програму спільної діяльності на 2021-2023 роки (Кремень, 2021c). Виконувалися спільні заходи з іншими міністерствами, зокрема з Міністерством соціальної політики, Міністерством молоді та спорту, Міністерством внутрішніх справ, Міністерством цифровізації.

Значно розширено співпрацю з Комітетом Верховної Ради України з питань освіти, науки та інновацій, іншими парламентськими комітетами, народними депутатами, істотно зросла їх підтримка діяльності НАПН України (Луговий та ін., 2021b)

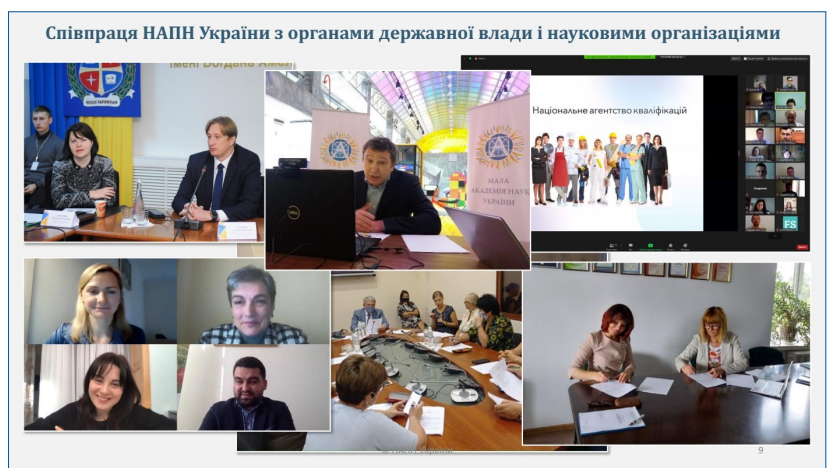


Посилено взаємодію з органами забезпечення якості освіти - Національним агентством із забезпечення якості вищої освіти та Державною службою якості освіти України. Реалізовано низку положень Меморандуму про співпрацю між НАПН України та цією Державною службою.

Уперше розпочато діяльність за Програмою спільної діяльності Національної академії наук України і Національної академії педагогічних наук України на 2020-2022 роки (Кремень, 2020b; Кремень та ін., 2020b). Традиційно НАПН України плідно взаємодіяла з усіма національними галузевими академіями наук.

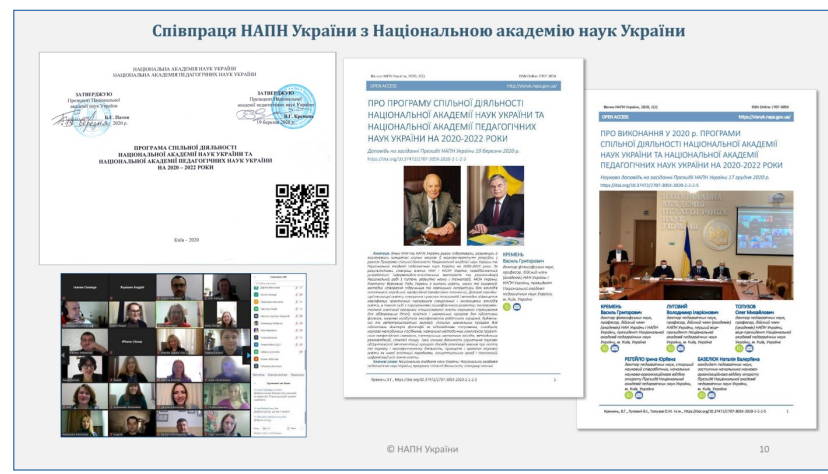

Подальшого розвитку набула співпраця НАПН України з Національним Еразмус+ Офісом щодо реалізації проєктів міжнародного співробітництва за програмою Еразмус+ у сфері вищої, фахової передвищої та професійної (професійно-технічної) освіти. Вчені НАПН України брали активну участь у реалізації європейської програми «Горизонт 2020» щодо розвитку наукової сфери.

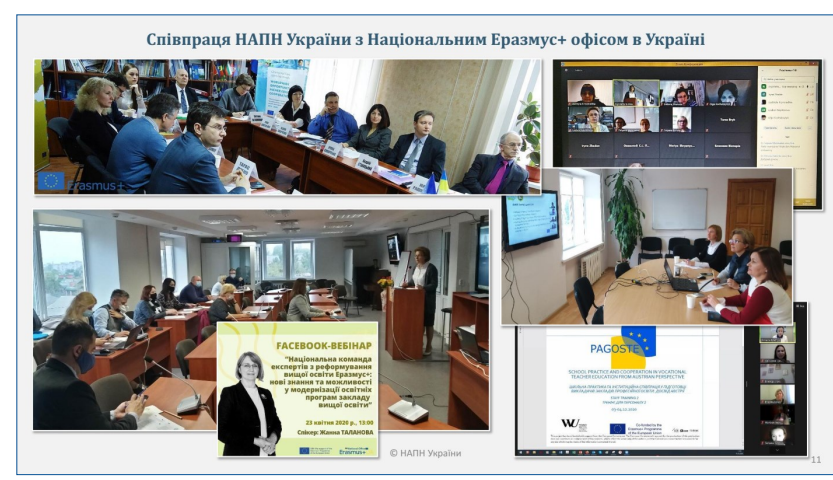

У 2020 р. НАПН України звітувала перед Науковим комітетом Національної ради України з питань розвитку науки і технологій за діяльність у 2018-2019 рр. (Кремень, 2020а), за результатами звіту продовжила зусилля з власної модернізації в контексті реформування наукової сфери. Зокрема, розширено конкурсні засади виконання наукових досліджень, розпочато успішну участь у конкурсах проєктів наукових досліджень Націона- льного фонду досліджень України, запропоновано заходи до урядового плану реформування НАПН України у 2020-2021 рр., загальними зборами схвалено нову редакцію Статуту академії тощо.

При цьому НАПН України незмінно керувалася тим, що за законодавством відповідальна за якісне наукове і методичне забезпечення освітньої сфери, продуктивну дослідницьку діяльність у галузі освіти, педагогіки і психології, ефективну підготовку і підвищення кваліфікації освітянських кадрів з метою розвитку найбільшої гуманітарної сфери - освіти. Нині у ній (без тимчасово непідконтрольних територій) функціонує 33 тис. закладів, навчається понад 8 млн здобувачів освіти, зайнято 1,3 млн освітян.

Для виконання основних завдань, визначених законами, указами, іншими актами законодавства та статутом НАПН України, у складі академії функціонують 10 наукових інститутів, Український науково-методичний центр практичної психології і соціальної роботи, ДЗВО «Університет менеджменту освіти» та Державна науково-педагогічна бібліотека України імені В.О. Сухомлинського.

У цих колективах, що сукупно забезпечують усі ланки освіти, у 2020 р. було зосереджено 817 штатних наукових працівників в еквіваленті повної зайнятості, з них 603 (73,8 \%) за основним місцем роботи, з яких 436 (72,3\%) із науковими ступенями, зокрема докторів наук - 133 (22,1%). Кількість докторів наук з-поміж цієї категорії вчених збільшилася на 11 осіб.

Крім того, в академії працювало 137 науковопедагогічних працівників, з них 109 (79,6 \%) за основним місцем роботи, з яких 87 (79,8\%) 3 науковими ступенями, а також 45 педагогічних працівників.

Станом на 1 січня 2021 р. 3-поміж членів НАПН України 75 дійсних членів (академіків) та 88 членівкореспондентів. Серед них 1 Герой України, 63 заслужених діяча науки і техніки України, 64 заслужених працівника освіти України, 2 заслужених працівника вищої школи, 1 заслужений економіст України, 4 заслужених юристи, 1 заслужений учитель. 3-поміж академіків і членівкореспондентів $73 \%$ представляють зовнішні заклади освіти і наукові установи всієї України. Також у складі академії 36 іноземних членів та 25 почесних академіків. У 2020 р. почесними академіками обрано С.М. Аржевітіна, П.М. Кулікова і Г.Г. Півняка. На превеликий жаль, протягом звітного періоду пішли з життя дійсні члени (академіки) Я.Б. Олійник, О.Я. Савченко та члени- 
кореспонденти В.В. Голуб, П.В. Лосюк, М.Ф. Степко. Уже в цьому році НАПН і вся освітянська спільнота втратили академіків В.І. Бондаря і М.І. Жолдака та члена-кореспондента Ю.І. Горобця.

Зосередження, збереження і посилення потужного кадрового потенціалу загальнонаціональної ваги в одному науковому центрі має значні переваги для відповідної координації i цілісності досліджень, їх ефективності.

Розвитку академії сприяла системна робота 3 молодими вченими, їх радами в академії та ії установах. У 2020 р. молодими вченими виконано сім прикладних наукових досліджень (Луговий та ін., 2021a).

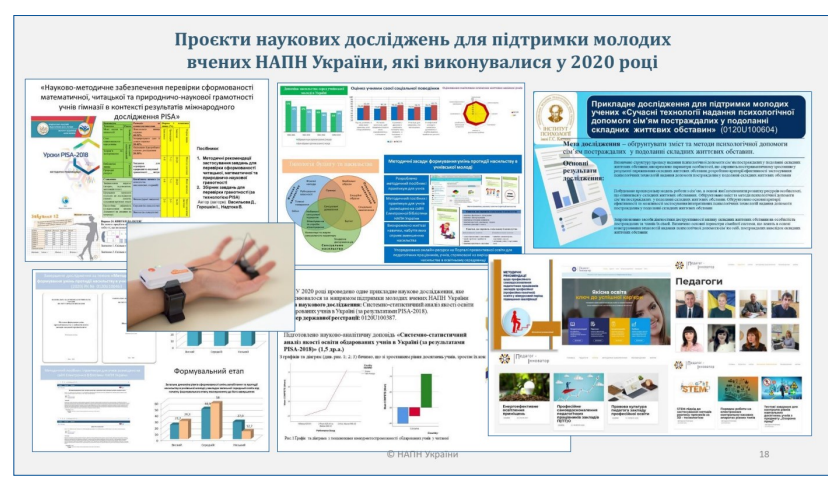

За вагомі досягнення та особистий внесок у розвиток вітчизняної освіти та науки у 2020 р. присуджено:

- премію Президента України для молодих вчених за наукову роботу "Науково-методичні засади здоров'язбережувального використання програмно-апаратних засобів учнями 5-9 класів у закладах загальної середньої освіти» А.С. Сухіх (Інститут інформаційних технологій і засобів навчання НАПН України);

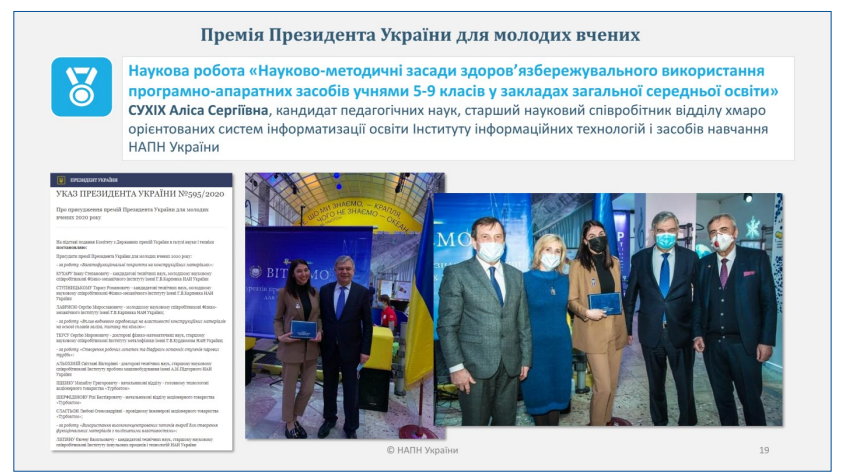

- Державну іменну стипендію найкращим молодим вченим для увічнення подій Револючії Гідності та вщанування подвигу Героїв України Героїв Небесної Сотні у номінації «стипендія імені Юрія Поправки» М.М. Павлюк (Інститут психології імені Г.С. Костюка НАПН України);
- стипендію Кабінету Міністрів України для молодих вчених: І.Г. Губеладзе (Інститут соціальної та політичної психології НАПН України); І.О. Горошкіну (Інститут педагогіки НАПН України); Є.В. Степурі (Інститут психології імені Г.С. Костюка НАПН України).

У цілому в НАПН України відповідно до цілей і пріоритетів державної освітньої політики у 2020 р. в її установах виконувалися 103 наукових дослідження, з яких 43 (42\%) фундаментальних і 60 (58\%) прикладних. У 2020 р. оптимізовано співвідношення фундаментальних і прикладних досліджень на користь прикладних. Крім того, дійсні члени (академіки) і члени-кореспонденти НАПН України виконували 163 індивідуальних дослідження.

Усього за результатами наукових досліджень вченими установ академії та членами НАПН України опубліковано понад 3,1 тис. праць, у тому числі 128 монографій, 35 підручників, 202 навчальні програми і посібники, 66 методичних посібників і рекомендацій, 6 словників і довідників, 455 збірників наукових праць, понад 1,7 тис. статей у фахових виданнях та більше 500 інших видів видавничої продукції.

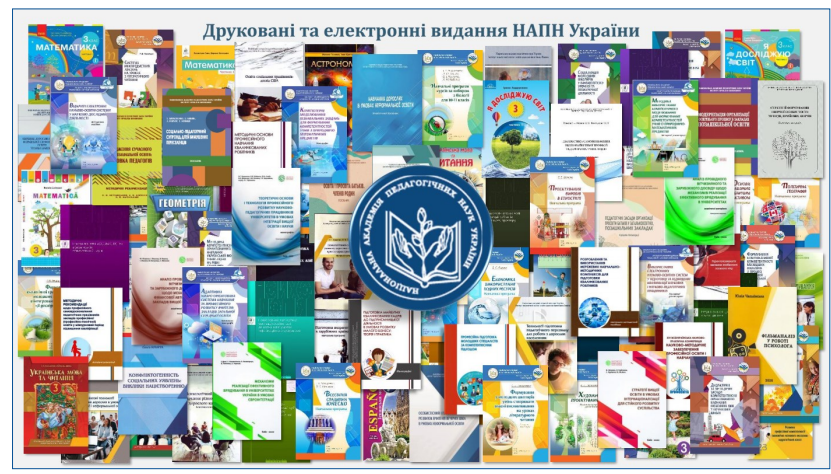

В установах академії за результатами завершених у 2020 р. 23 фундаментальних і 24 прикладних досліджень підготовлено 1862 од. наукової, виробничо-практичної, навчальної і довідкової продукції. Зокрема, наукової (монографії, препринти) - 31, виробничо-практичної (методичні посібники, практичні посібники, методичні рекомендації, практикуми, інше) - 70, навчальної (підручники, навчальні посібники, навчальні програми) - 64, довідкової (словники) - 1, статей - 1696. 3 них друкованих та електронних видань: наукової продукції - 18, виробничопрактичної - 43, навчальної - 31, статей - 1696.

Згідно з планами випуску наукової, виробничопрактичної, навчальної та довідкової продукції установ НАПН України, підготовленої у 2020 р. за 
результатами наукових досліджень за кошти державного бюджету, випущено 18 найменувань друкованих (загальним тиражем понад 4,6 тис. примірників) та 86 найменувань електронних видань.

у 2020 р. переможцями конкурсів наукових і науково-технічних проєктів Національного фонду досліджень України стали три проєкта НАПН України. За напрямом «Наука для безпеки людини та суспільства» отримано грантову підтримку двох наукових досліджень: «Психологічна підтримка літніх осіб у період карантину» (Інститут педагогічної освіти і освіти дорослих імені Івана Зязюна НАПН України) та «Подолання наслідків пандемії COVID-19 у діяльності психологічної служби системи освіти» (Український науково-методичний центр практичної психології і соціальної роботи НАПН України). За напрямом «Підтримка досліджень провідних та молодих вчених» - «Хмаро орієнтовані системи відкритої науки у навчанні і професійному розвитку вчителів» (Інститут інформаційних технологій і засобів навчання НАПН України).

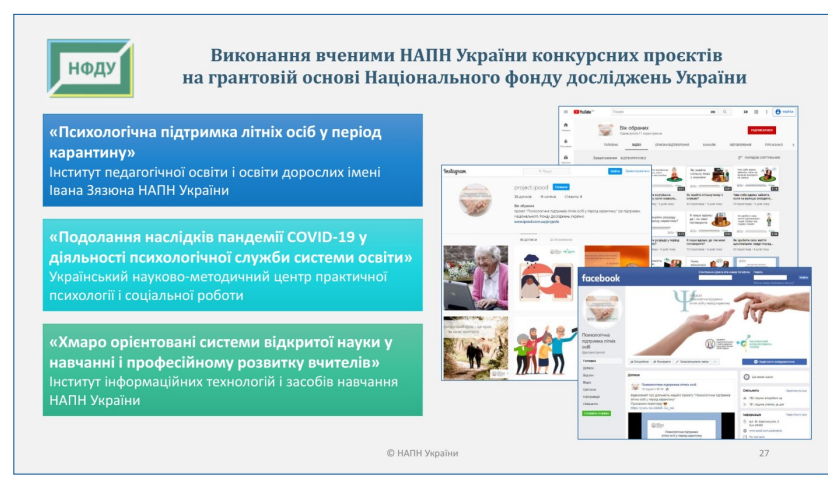

Найважливіші наукові здобутки у 2020 р. докладно, зокрема із зазначенням відповідних відділень і установ, висвітлено у згаданих вище звітних матеріалах. Серед найбільш значущих результатів такі.

По відділенню загальної педагогіки та фрілософії освіти і його установам: Інститут проблем виховання, Державна науково-педагогічна бібліотека України імені В.О. Сухомлинського та окремі підрозділи Інституту педагогіки НАПН України.

Визначено актуальні принципи становлення сучасного інформаційного світу, ознакою якого $€$ цифровізація, візуалізація, віртуалізація усіх аспектів життя, і розвитку людини в ньому в умовах інформаційно-цифрової реальності.

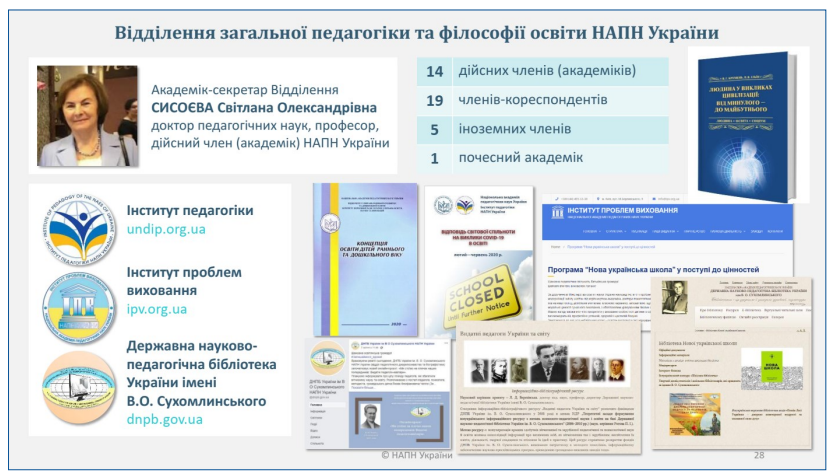

Розроблено та видано інноваційну Концепцію освіти дітей раннього та дошкільного віку спільно з підкомітетом з питань раннього розвитку та дошкільної освіти Комітету Верховної Ради України з питань освіти, науки та інновацій. Підготовлено та оприлюднено аналітичну довідку «Відповідь світової спільноти на виклики COVID19 в освіті (лютий - червень 2020 р.)». Виявлено тенденції розвитку шкільної освіти в країнах ЄC, США та Китаї з окресленням перспективного досвіду для України з огляду на реалізацію Концепції «Нова українська школа». Розроблено методики формування соціально активної відповідальної особистості, патріота й громадянина у закладах вищої освіти. Визначено зміст діяльності переміщених університетів як нового типу закладів України. Здійснено класифікацію епістолярної спадщини науковою, методичною, персоналістичною ознаками. Уточнено науково-методичні засади діяльності освітянських бібліотек із забезпечення інформаційних потреб користувачів в сучасних умовах, поповнено інформаційний ресурс «Бібліотека Нової української школи».

По відділенню психології, вікової фрізіології та дефектології і його установам: Інститут психології імені Г.С. Костюка, Інститут спеціальної педагогіки і психології імені Миколи Ярмаченка, Інститут соціальної та політичної психології, Український науково-методичний центр практичної психології і соціальної роботи.

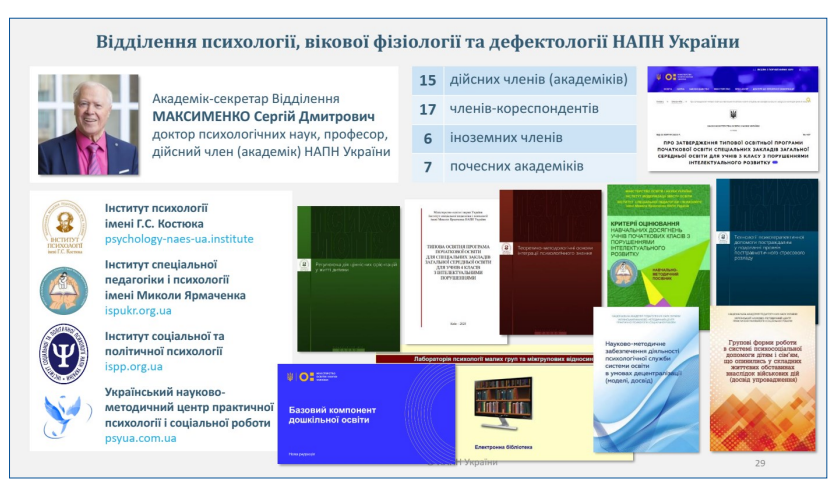


Спільно з вченими Інституту проблем виховання НАПН України та фахівцями МОН України оновлено Базовий компонент дошкільної освіти (державний стандарт дошкільної освіти), який затверджено наказом МОН України 12 січня цього року. Обґрунтовано підхід до оцінки ціннісних орієнтацій дітей дошкільного віку як пріоритетних індикаторів особистісного зростання. Розроблено модель, систему методів і технологій надання психологічної допомоги постраждалим у подоланні складних життєвих обставин. Створено концепції групових процесів у складних соціальних ситуаціях гібридної війни, вимушеної міграції переселенців, соціальних і економічних трансформацій перехідного суспільства; творення етнокультурними групами спільного образу майбутнього у ситуації конфліктної історичної пам'яті; захисної поведінки групи в умовах колективної травми і групових інформаційних травм. Розроблено транзактну модель механізмів взаємодії з дітьми усиновлювачів, які проживають складні соціальні ситуації; моделі символізації групового досвіду долання складних соціальних ситуацій як процесу посттравматичного зростання суб'єктів взаємодії у малих групах, низку відповідних розвивальних засобів та алгоритм дистанційного ведення кризових онлайн-груп. Запропоновано моделі управління і науково-методичного забезпечення психологічної служби на рівнях «заклад освіти - територіальна громада», «територіальна громада район», «район - область»; розроблено програми занять і методи групової роботи з учнями у процесі психологічного супроводу дітей і сімей, які зазнали травматичного досвіду внаслідок військових дій. Підготовлено та впроваджено Типову освітню програму для навчання дітей 3 інтелектуальними порушення (для 3-4 класів). Запропоновано сучасні моделі організації навчання, психологічного супроводу і реабілітації дітей з порушеннями когнітивного розвитку. Визначено основні напрями модернізації змісту освіти незрячих дітей та з порушеннями зору; для таких дітей обґрунтовано принципи побудови діагностичних методик, розроблено вимоги до наочного матеріалу для роботи психолога з ними. Розроблено теоретичні і методичні засади, модель організації білінгвального навчання глухих і слабкочуючих дітей, апробовано систему навчальних вправ і завдань.
По відділенню загальної середньої освіти і його установам: Інститут педагогіки, Інститут інформаційних технологій і засобів навчання та Інститут обдарованої дитини НАПН України.

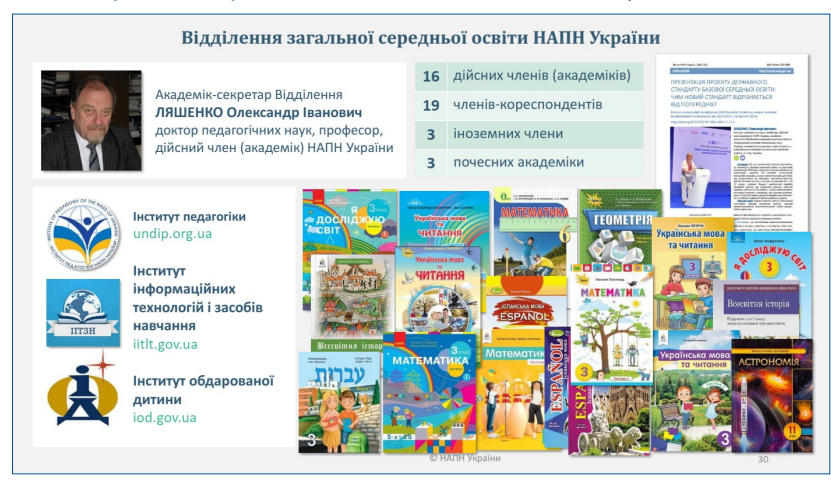

Сформовано науково-методичне і дидактичне забезпечення ефективної реалізації освітньої програми для 3-4 класів, розробленої під керівництвом академіка О.Я. Савченко, за якою працює більшість початкових шкіл України. Створено й опубліковано 14 нових підручників для 3 класу з мов, математики, інтегрованого курсу «Я досліджую світ», у яких реалізовано новий зміст освіти та інноваційні підходи до його вивчення. Видано методичні посібники з організації освітнього процесу в початковій школі. Завершено розроблення спільно з МОН України нового Державного стандарту базової середньої освіти, який затверджено урядовою постановою. Розроблено нові методики компетентнісно орієнтованого навчання української мови, української літератури, окремих мов національних меншин, математики, історії в закладах загальної середньої освіти. Створено 23 нових підручники з різних предметів, які за результатами Всеукраїнського конкурсу і вибору педагогів отримали державне фінансування, видані масовими тиражами і використовуються в освітній практиці. Розроблено моделі державної підсумкової атестації випускників гімназій у формі зовнішнього незалежного оцінювання, з'ясовано умови їх вибору і реалізації. Запропоновано методологію коректного врахування успішності шкільного навчання у показниках зовнішнього незалежного оцінювання на основі методів кваліметрії. Обґрунтовано мультиплікативний підхід до об'єднання окремих оцінок атестату для отримання інтегративної оцінки успішності шкільного навчання. Розроблено архітектуру і складники адаптивної інтелектуальної інформаційної системи навчання, яка забезпечує персоналізацію інформаційної взаємодії користувача 3 
системою. Створено програмні засоби, що реалізують функції персоналізованого інтелектуального тьютора. Обґрунтовано моделі адаптивної хмаро орієнтованої системи навчання і професійного розвитку вчителів закладів загальної середньої освіти, інформаційно-аналітичної підтримки педагогічних досліджень на основі електронних систем відкритого доступу. Запропоновано концептуальну модель системи комп'ютерного моделювання та методику їі використання для формування компетентностей учнів з природничо-математичних предметів.

По відділенню професійної освіти і освіти дорослих та його установам: Інститут професійнотехнічної освіти та Інститут педагогічної освіти і освіти дорослих імені Івана Зязюна НАПН України.

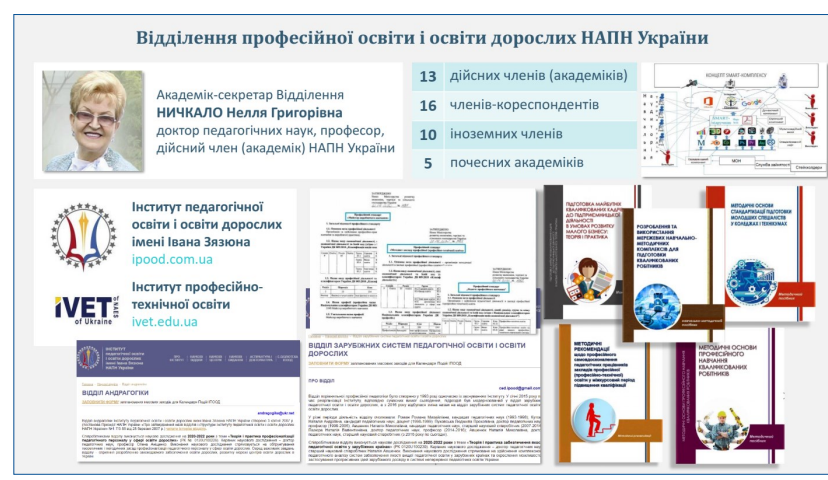

У сфері професійної (професійно-технічної) освіти: обґрунтовано концепції проєктування і розроблення SMART-комплексів для закладів професійної (професійно-технічної) освіти аграрної, будівельної та машинобудівної галузей, а також оцінювання якості підготовки фахівців у закладах фахової передвищої освіти; створено педагогічну систему підготовки кваліфікованих кадрів до підприємницької діяльності; розроблено методики формування професійної компетентності майстрів виробничого навчання та професійної підготовки кваліфікованих робітників 3 елементами дуальної форми навчання, проєктування освітньо-виробничого середовища закладу та розвитку соціального партнерства в ньому в умовах цієї форми навчання; підготовлено проєкти професійних стандартів на компетентнісній основі «Педагог професійного навчання», «Майстер виробничого навчання», «Методист закладу професійної (професійно-технічної) освіти».

У сфері педагогічної освіти і освіти дорослих: розроблено навчальну програму курсу «Професійна компетентність андрагога» 3 урахуванням індивідуальних запитів, освітніх потреб педагогічного персоналу у сфері освіти дорослих, тенденцій професіоналізації освіти дорослих, досвіду розроблення подібних національних і зарубіжних навчальних програм; схарактеризовано механізми й інструменти забезпечення якості професійної підготовки педагогічних працівників в Австралії, Великій Британії, США; окреслено стратегічні напрями державної освітньої політики з урегулювання основних чинників, що впливають на підвищення якості професійної підготовки вчителів. Розроблено рекомендації з використання в Україні конструктивних ідей зарубіжного досвіду забезпечення якості вищої педагогічної освіти.

По Відділенню вищої освіти та його установам: Інститут вищої освіти та ДЗВО «Університет менеджменту освіти» НАПН України.

Обґрунтовано стратегії вищої освіти в умовах інтернаціоналізації для стійкого розвитку суспільства. Визначено підходи, механізми, показники і критерії оцінювання якості вищої освіти в умовах євроінтеграції. Розроблено систему показників для оцінювання ефективності діяльності університетів України та запропоновано рекомендації щодо ії оцінювання для національного, секторального та інституційного рівнів. Сформульовано науково обґрунтовані критерії і показники національного рейтингування закладів вищої освіти, формульного розподілу видатків між ними, цільові показники діяльності закладу вищої освіти, обґрунтовано механізми розширення фінансової автономії закладів вищої освіти. Доведено необхідність трансформації управлінських і методичних засад організації навчальної роботи, внутрішньої та зовнішньої комунікації закладів вищої освіти, а також розвитку технології дистанційного інформаційно-комп'ютерного спілкування суб'єктів освітнього процесу. Розроблено освітню платформу «Профосвіта» як інноваційне навчально-цифрове середовище для безперервного професійного розвитку фахівців через формальну, неформальну та інформальну освіту.

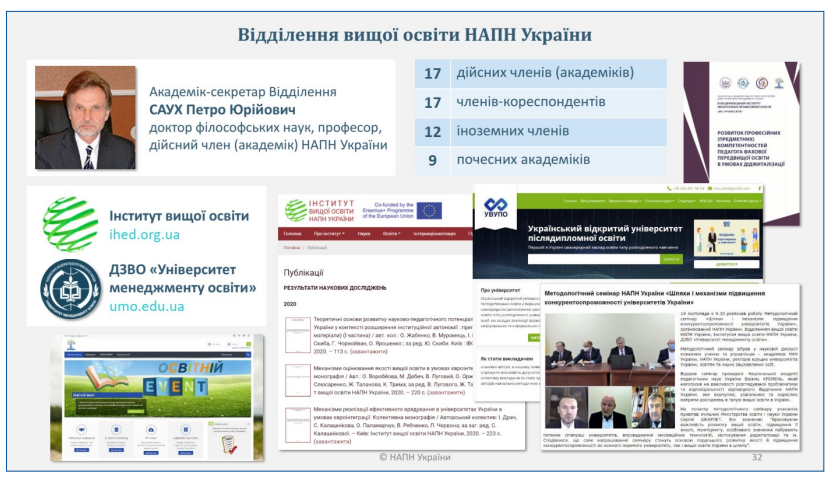


Створено і впроваджено цифровий програмнометодичний комплекс «Розвиток професійних (предметних) компетентностей педагога фахової передвищої освіти в умовах діджиталізації». На основі філософського аналізу виявлено радикальні змістові трансформації функцій освіти в умовах глобалізації, які зумовили новий ії світоглядний ідеал, пов'язаний із культурно-національною самоідентифікацією; схарактеризовано риси духовності в добу «товарної» концептуалізації освіти, окреслено принципи сучасної духовної кризи.

Вчені підвідомчих установ НАПН України у ході 85 експериментів різних рівнів здійснювали експериментальну діяльність у 1424 закладах освіти МОН України. Під науковим керівництвом вчених НАПН України виконується 35 всеукраїнських експериментів (два мають статус академічних), що охоплюють різні рівні та складники освіти.

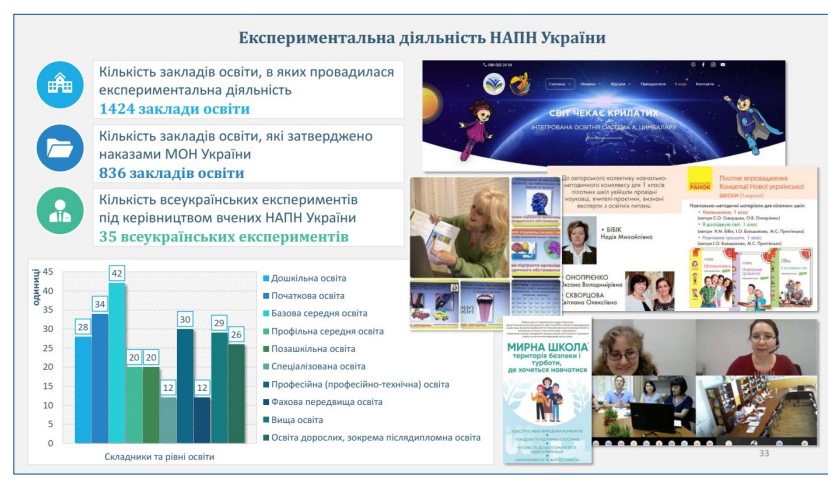

Результати наукових досліджень, що проводилися підвідомчими установами за кошти державного бюджету, упроваджувалися у закладах освіти, установах, організаціях, на підприємствах, в органах державної влади та органах місцевого самоврядування. На різних етапах і рівнях впроваджено 92 із 166 розробок, підготовлених за завершеними у 2020 р. фундаментальними та прикладними науковими дослідженнями.

Впровадженню здобутих результатів сприяло розміщення праць в Електронній бібліотеці НАПН України, яких у звітному році внесено понад 2,8 тис. У цілому на кінець 2020 р. у бібліотеці представлено майже 23 тис. повнотекстових ресурсів, які завантажено понад 7,2 млн разів, 3 них майже 2,5 млн у 2020 р. порівняно з 1 млн у 2018 р. Упродовж 2020 р. налічувалося понад 67 тис. користувачів бібліотеки (на 20 тис. більше порівняно з 2019 р.), здійснено 658 тис. переглядів сторінок, 120 тис. сеансів зі 146 країн світу (найбільше користувачів з України - 89 \%).

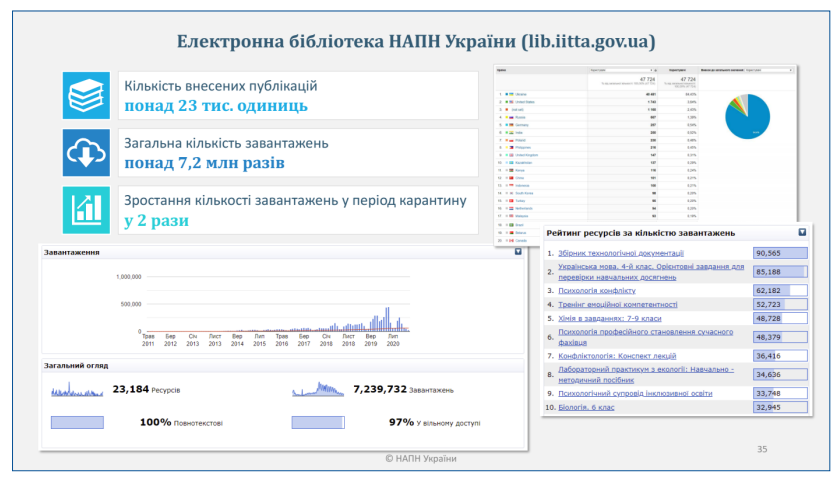

Активізовано роботу з представлення діяльності вчених НАПН України в інформачійному науково-освітньому просторі. Дійсні члени, члени-кореспонденти та вчені установ НАПН України опублікували понад 330 статей, що в 1,9 рази більше порівняно з 2019 р. та у 4 рази більше порівняно з 2018 р. у наукових виданнях, що індексуються у наукометричних базах даних Scopus та Web of Science Core Collection. У 2 рази порівняно з 2019 р. та у 3,8 раза порівняно 3 2018 р. збільшилася частка вчених (близько 230 науковців) підвідомчих установ і дійсних членів (академіків) та членів-кореспондентів НАПН України, які опублікували статті у престижних виданнях. На 304 од. порівняно з 2019 р. зросла кількість публікацій вчених підвідомчих установ НАПН України англійською та іншими іноземними мовами.

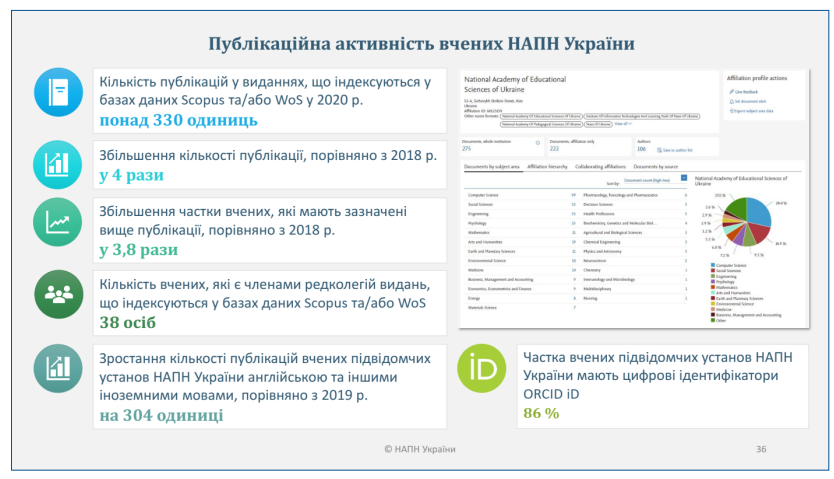

у 2020 р. до Переліку наукових фахових видань України категорій «А» та «Б» внесено 25 наукових періодичних видань НАПН України.

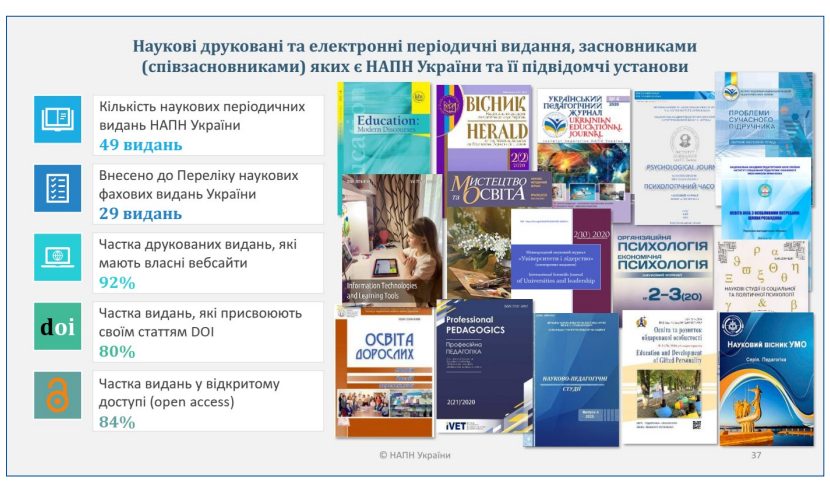


Опубліковано третій номер англомовного наукового періодичного видання НАПН України «Education: Modern Discourses», який індексується y Crossref, Directory of Open Access Journals, European Reference Index for the Humanities and Social Sciences, Index Copernicus International тощо.

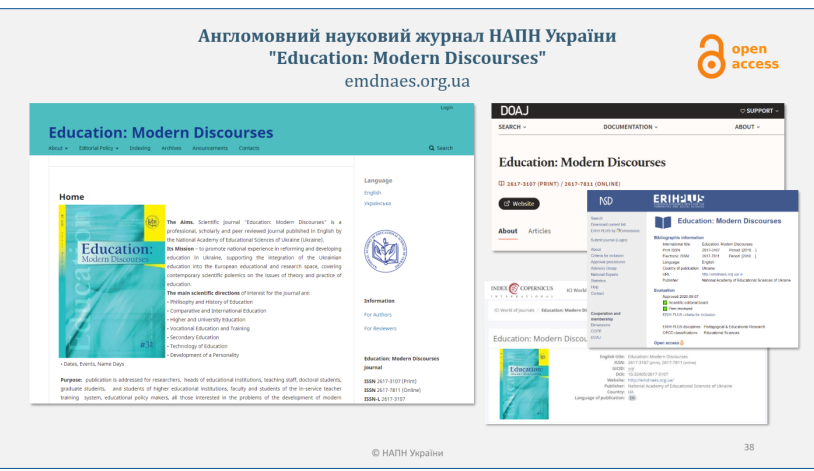

Здійснюється випуск електронного наукового періодичного видання відкритого доступу «Вісник Національної академії педагогічних наук України». За даними Google Analytics у звітному році налічувалося понад 7,5 тис. користувачів вебсайту видання, 58,0 \% з яких вивчали опубліковані матеріали 3 мобільних пристроїв (смартфонів та планшетів). Найбільше користувачів з України (83,2 \%) та США (14,6 \%).

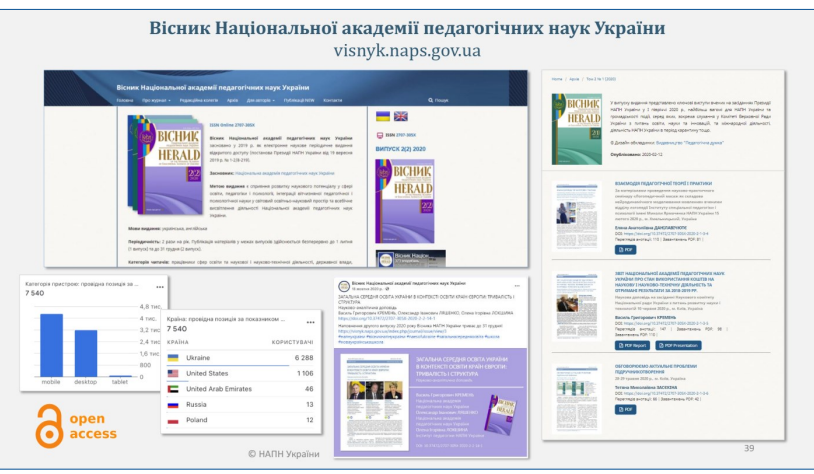

Електронне наукове періодичне видання «Інформаційні технології і засоби навчання» (засновник - Інститут інформаційних технологій і засобів навчання НАПН України; співзасновники: ДзВО «Університет менеджменту освіти» НАПН України, Державна наукова установа «Інститут модернізації змісту освіти» МОН України) представлено в базі даних Emerging Sources Citation Index (ESCl) Web of Science Core Collection компанії Clarivate. Видання є провідним в Україні (за даними Бібліометрики української науки посідає 10 місце серед наукової періодики України) і популярним за кордоном. Упродовж 2020 р. здійснено майже 1 млн переглядів його сторінок

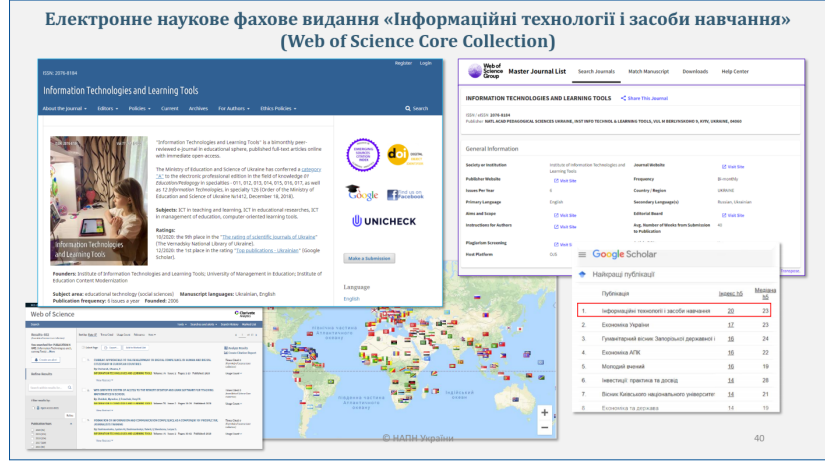

понад 26 тис. користувачів із 193 країн світу (найбільше з України - 48,7 \%, США - 14,6\% та Японії - 8,8 \%).

Вчені НАПН України проводили незалежну наукову експертизу. Подано пропозиції до понад 90 законодавчих, нормативно-правових актів, державних рішень і програм, освітніх інновацій та інформаційно-аналітичних матеріалів, більш як 900 рукописів видавничої продукції; до понад 120 од. навчальної літератури, засобів навчання та навчального обладнання для закладів дошкільної, початкової, середньої (базової і профільної) освіти; понад 220 відзивів на дисертації (з них $39 \%$ - на здобуття наукового ступеня доктора наук). Більше 130 провідних вчених НАПН України брали участь як наукові експерти та фахові представники у діяльності експертних, акредитаційних, робочих груп і комісій, агентств, програмних комітетів, організацій, підприємств тощо.

У НАПН України забезпечено завершений цикл підготовки здобувачів наукових ступенів доктора фрілософії та доктора наук через аспірантуру і докторантуру 11 підвідомчих установ у межах 65 наукових шкіл вчених академії. у 2020 р. показники ефективності підготовки аспірантів і докторантів за державним замовленням зросли у порівнянні з 2019 р.: в аспірантурі - на $11 \%$, у докторантурі - на $14 \%$, зокрема за кошти юридичних і фізичних осіб - на $60 \%$.

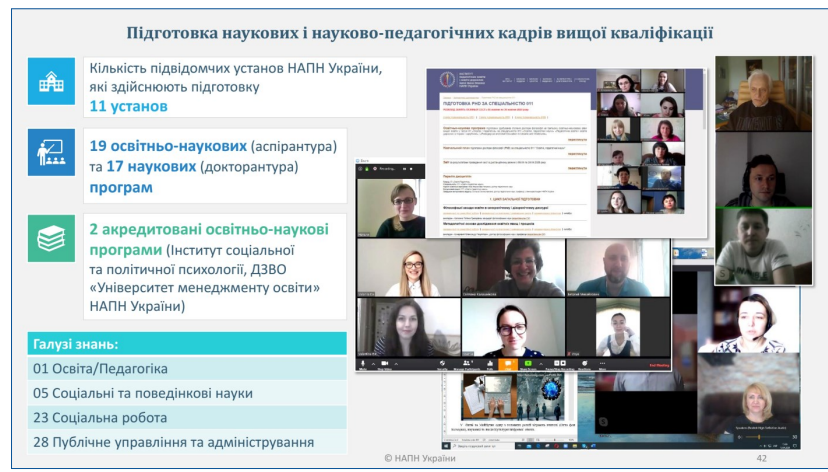

Атестація наукових і науково-педагогічних кадрів вищої кваліфікації здійснювалася в 


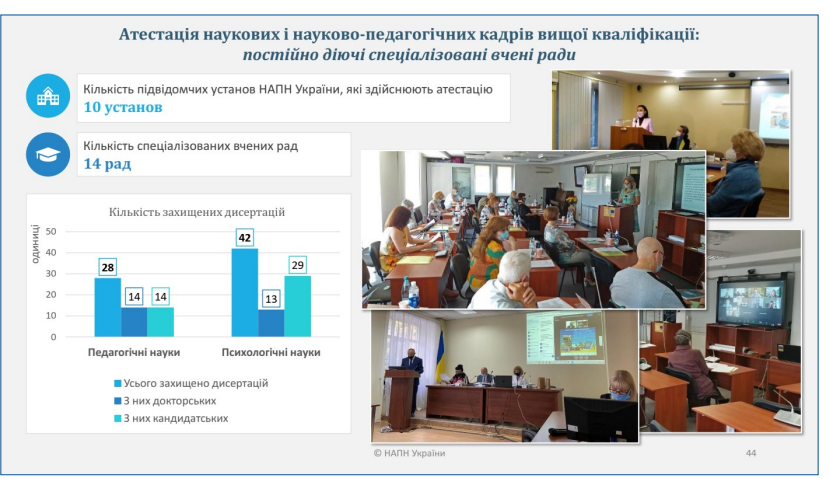

14 спеціалізованих вчених радах, що діють у 10 підвідомчих установах. За минулий рік захищено 27 докторських і 43 кандидатських дисертацій.

До роботи Міжвідомчої ради з координації досліджень у галузі освіти, педагогіки і психології залучено понад 80 провідних вчених України та розглянуто 297 тем дисертаційних досліджень, надісланих від 78 наукових установ і закладів вищої освіти. У цілому скориговано понад двох третин тем дисертаційних досліджень здобувачів наукового ступеня доктора наук і близько половини тем - здобувачів наукового ступеня доктора філософії з огляду на актуальність та інноваційність.

Підготовка на першому (бакалаврському) i другому (магістерському) рівнях вищої освіти провадилася у ДзВо «Університет менеджменту освіти» та в Інституті професійно-технічної освіти НАПН України.

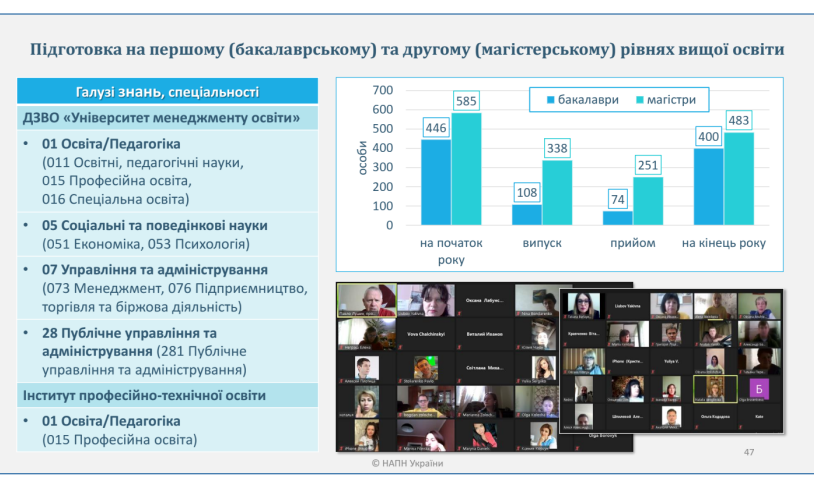

Підвищення кваліфікації кадрів здійснювалося у ДзВО «Університет менеджменту освіти»,

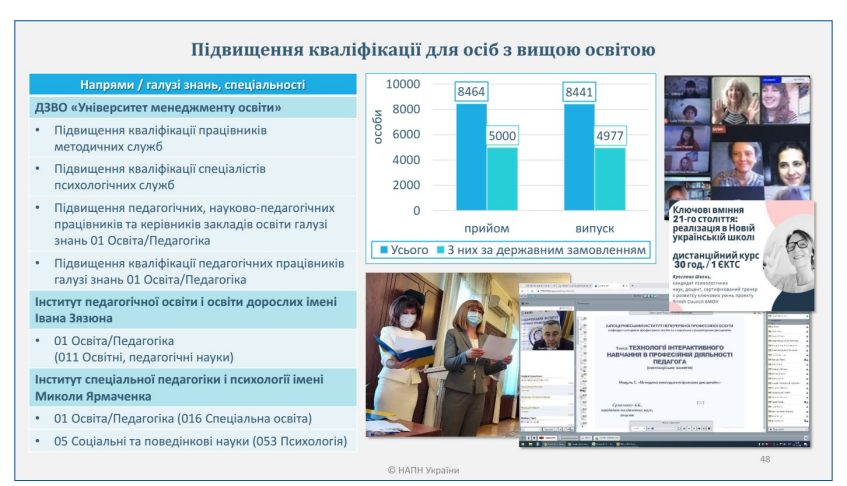

Інституті спеціальної педагогіки і психології імені Миколи Ярмаченка та Інституті педагогічної освіти і освіти дорослих імені Івана Зязюна. Підвищили кваліфікацію понад 8 тис. керівників, науково-педагогічних і педагогічних працівників освітньої сфери, з них 5 тис. осіб - за державним замовленням.

Вчені НАПН України були активними учасниками трьох міннародних виставок з питань освіти,

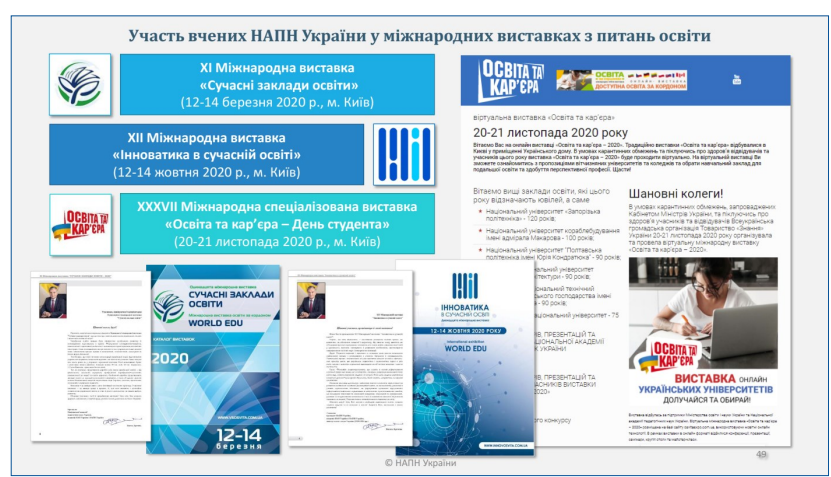

у рамках яких провели 54 онлайн заходи, та за представлені наукові розробки відзначені нагородами і медалями, а також відповідно до планів роботи взяли участь у понад 160 інших науково-практичних заходах.

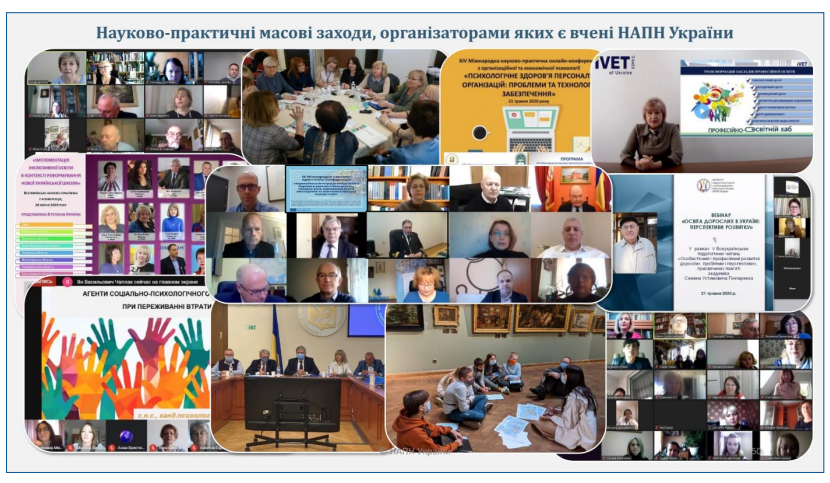

У НАПН України провадилася активна міжнародна діяльність, що здійснювалася в рамках близько 40 міжнародних освітніх і наукових проєктів і програм, зокрема Еразмус + і Горизонт 2020, Британської ради в Україні, Європейського фонду підготовки, Представництва ООН в Україні, Представництва DVV International в Україні, Ради Європи, Світового банку, ЮНЕСКО, ЮНІСЕФ та інших міжнародних організацій і фондів; наукової співпраці з 36 іноземними членами НАПН України, які представляють 11 країн світу, науковими установами і закладами освіти відповідно до 29 угод про співробітництво; експертної діяльності у понад 50 міжнародних організацій; проведення 75 міжнародних науково-практичних заходів; підвищення професійного розвитку та стажування за 


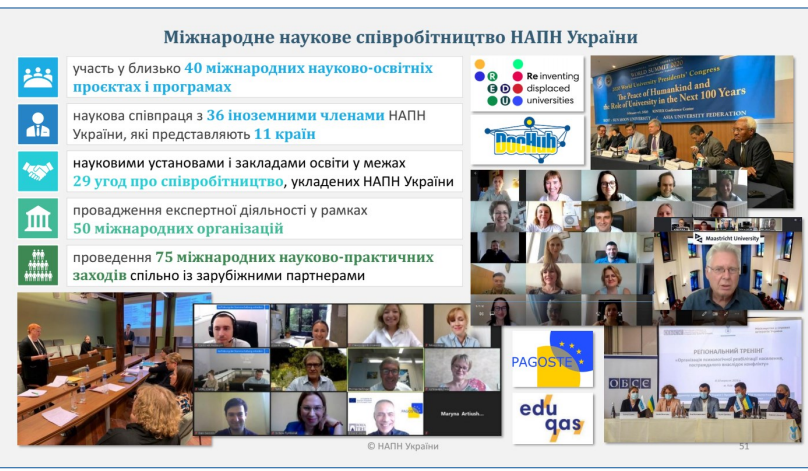

кордоном 50 вчених НАПН України тощо. Зокрема Інститутом вищої освіти НАПН України у 2020 р. розпочато великий європейський проєкт співпраці на 1,5 млн євро «Відродження переміщених університетів: посилення конкурентоспроможності, підтримка громад», у якому Інститут виступає грантоутримувачем.

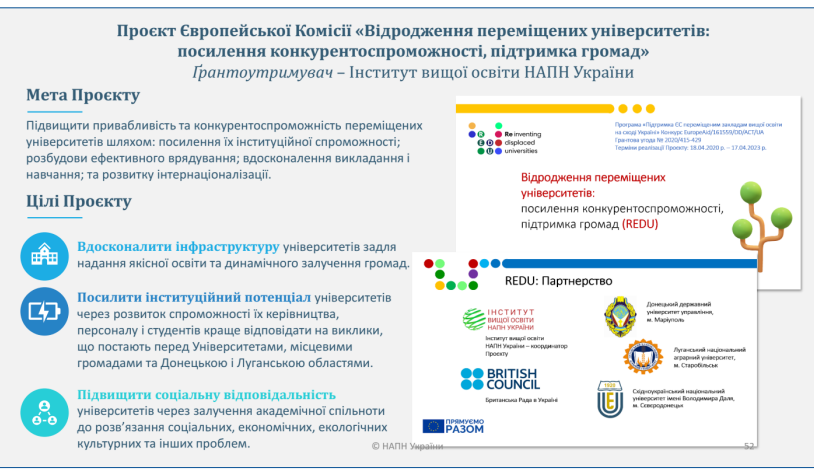

У контексті Концепції розвитку цифрової економіки та суспільства України на 2018-2020 роки та ураховуючи запровадження з 12 березня 2020 р. в Україні карантину, пріоритетним завданням цифровізації наукової діяльності НАПН України та іiї підвідомчих установ було забезпечення ефективної дистанційної роботи наукових та інших працівників академії, що здійснювалося шляхом використання IT-програм Zoom, Skype, Meet, YouTube тощо як засобу колективної комунікації; освоєння хмарних технологій Google та Microsoft для електронного документообігу; застосування цифрових технологій аналізу академічної доброчесності в працях вчених академії.

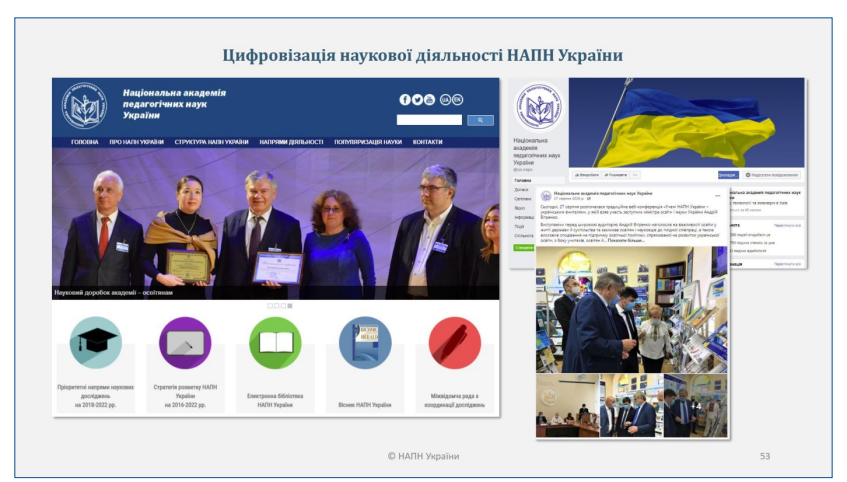

Особливої уваги заслуговує діяльність вчених НАПН України щодо психолого-педагогічного супроводу освітнього процесу, методичного забезпечення дистанційного навчання, провадження антикризового менеджменту підвищення кваліфікації педагогічних, науково-педагогічних і керівних кадрів освіти в умовах карантинних обмежень, зумовлених COVID-19.

Посилено роботу щодо висвітлення результатів діяльності НАПН України та підвідомчих установ на вебпорталі академії, в освітянських виданнях, через радіо і телебачення.

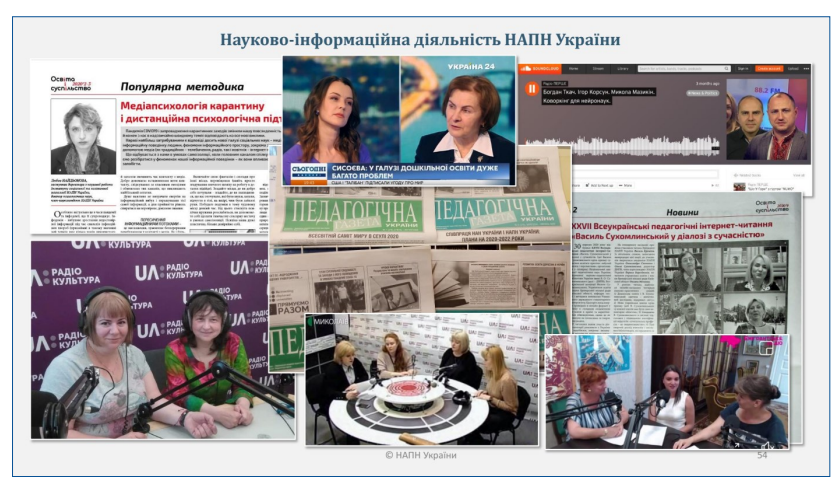

У 2020 р. в умовах карантинних обмежень в онлайн режимі відбулися дві сесії загальних зборів НАПН України: «Звіт про діяльність Національної академії педагогічних наук України у 2019 році та завдання на 2020 рік» (30 червня) та «Наукове забезпечення розвитку освіти дорослих в Україні» і «Про затвердження Статуту Національної академії педагогічних наук України в новій редакції» (20 листопада).

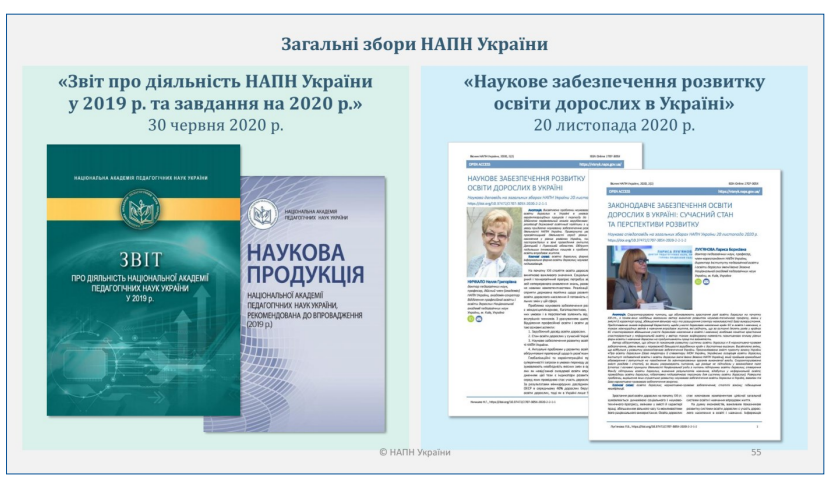

Проведено методологічні семінари «Дошкільна освіта в контексті ідей Нової української школи» (30 жовтня) та «Шляхи і механізми підвищення конкурентоспроможності університетів України» (19 листопада).

Проведено 14 (10 планових і 4 позачергових) засідань Президії НАПН України, на яких розглянуто понад 300 питань і прийнято відповідні постанови зі статутної діяльності НАПН України. 


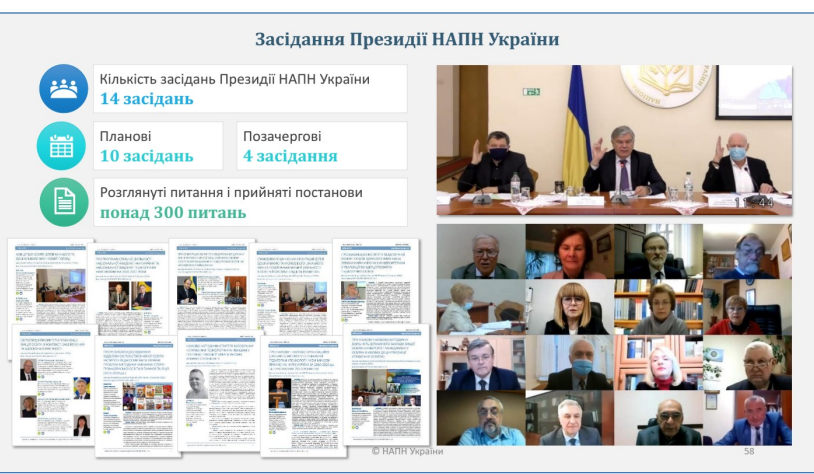

Зокрема, проаналізовано:

- наукову і науково-організаційну діяльність за 2016-2020 рр. та перспективи розвитку Інституту спеціальної педагогіки і психології імені Миколи Ярмаченка НАПН України, ДЗВО «Університет менеджменту освіти» в умовах децентралізації управління освітою;

- результати виконання підвідомчими установами наукових досліджень щодо науковометодичної стратегії запобігання негативним психологічним явищам у політико-правовій сфері в умовах воєнного конфлікту (Інститут соціальної та політичної психології НАПН України);

- проблеми методики навчання історії і громадянської освіти в ліцеї та гімназії (Інститут педагогіки НАПН України);

- світоглядні пріоритети гуманізації вищої освіти в контексті забезпечення та вдосконалення якості (Інститут вищої освіти НАПН України).

Обговорено проєкти:

- Концепції освіти дітей раннього та дошкільного віку, розробленої вченими відділень загальної педагогіки та філософії освіти і психології, вікової фізіології та дефектології НАПН України;

- Концепції психологічного супроводу освітніх реформ у діяльності психологічної служби в системі освіти України (Український науковометодичний центр практичної психології і соціальної роботи).

Значну увагу приділено:

- виконанню експериментальних досліджень всеукраїнського рівня Інститутом психології імені Г.С. Костюка та Інститутом соціальної та політичної психології НАПН України;

- впровадженню експериментального стандарту академічної наукової діяльності (Відділення загальної педагогіки та філософії освіти НАПН України спільно з Інститутом проблем виховання НАПН України).

НАПН України в 2020 р. отримано фрінансування 3 державного бюджету в сумі 215,3 млн грн. Порівняно з 2019 р. фінансування збільшилося на
15,0 млн грн або на 7,5 \%, що пов'язано з підвищенням посадових окладів і мінімальної заробітної плати. НАПН України отримано 28,1 млн грн за спеціальним фондом бюджету (власні надходження бюджетних установ), що на 2,2 млн грн (8,5 \%) більше, ніж у 2019 р. Загалом упродовж звітного року до НАПН України з усіх джерел фінансування надійшло 243,4млн грн. Питома вага фінансування за рахунок загального фонду бюджету становила 88,5 \%.

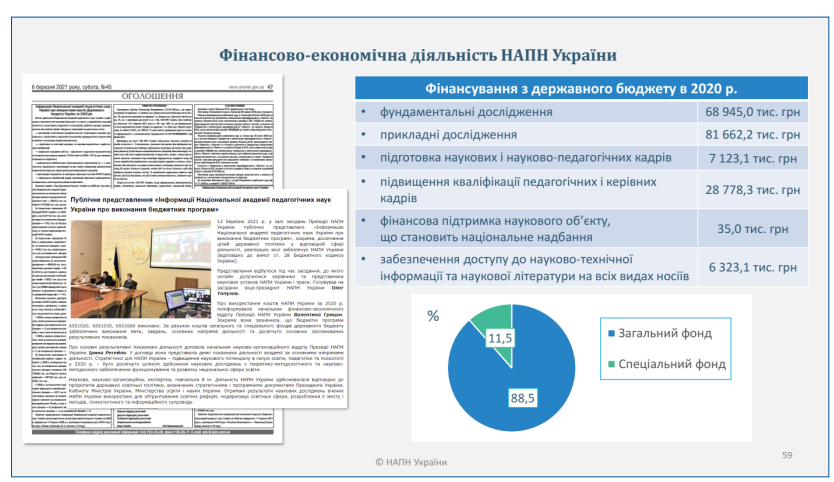

Водночас у 2020 р. тривав вплив чинників, в основному пов'язаних із загальним недофінансуванням наукової сфери в країні, що стримують розвиток НАПН України. 3-поміж них такі:

1. Недостатнє фінансування академії з огляду на складність і масштабність завдань та об'єктивно обмежені можливості комерціалізації результатів діяльність в освітянській сфері. Загалом наукові дослідження фінансуються в НАПН України в обсязі, що становить 0,05 \% фінансування освітньої сфери.

2. Неконкурентоспроможність заробітної плати. Середньомісячна заробітна плата на повну ставку працівників за загальним фондом у 2020 р. становила 9,4 тис. грн (середня заробітна плата у м. Києві в цей період - 17,1 тис. грн).

3. Кількаразове зниження прийому в аспірантуру і докторантуру через брак коштів гальмує омолодження наукових колективів.

4. Дефіцит фінансових можливостей для участі вчених, аспірантів і докторантів у повноцінній міжнародній науковій діяльності, закордонних конференціях, стажуваннях, публікаціях тощо.

5. Обмежені можливості в модернізації дослідницького, комп'ютерного і мультимедійного обладнання.

Водночас у НАПН України, її установах $\epsilon$ внутрішні невикористані резерви підвищення ефективності діяльності. Серед них:

1. Подальший аналіз та актуалізація тематики наукових досліджень і розробок НАПН України з 
метою концентрації фінансових, кадрових, матеріально-технічних ресурсів на проведенні наукових досліджень і розробок, спрямованих на вирішення актуальних проблем освіти, економіки і соціальної сфери країни, ліквідація подрібненості та дублювання напрямів виконання наукових досліджень науковими установами.

2. Розвиток наукової та науково-технічної діяльності установ НАПН України, збільшення масштабів та ефективності впровадження результатів наукових досліджень, частки прикладних досліджень, скорочення термінів виконання науково-дослідних робіт, підвищення публікаційної активності та ефективності у міжнародних наукометричних базах, розширення участі у міжнародному співробітництві, співпраці між науковими установами та споживачами наукової продукції всіх форм власності.

3. Оптимізація організаційної структури НАПН України, перепрофілювання та об'єднання окремих установ та їх підрозділів за результатами оцінювання їх діяльності та державної атестації.

4. Подальше розширення участі наукових установ НАПН України у міжнародних проєктних та грантових конкурсних відборах, насамперед за програмами Еразмус+ та Горизонт Європа на 2021-2027 рр.

5. Удосконалення розподілу фінансування наукових установ 3 урахуванням результатів ефективності їх діяльності та державної атестації у 2021 p.

6. Створення наглядових рад в УМО та наукових установах, забезпечення належного внутрішнього контролю за організаційною та фінансовогосподарською діяльністю.

У процесі модернізації НАПН України необхідно зберегти, закріпити і максимально розвинути ії сильні сторони і переваги, які важливі для теорії і практики освіти тепер і в перспективі та полягають у наступному.

1. НАПН України $є$ єдиним в Україні унікальним науковим центром, де зосереджений потужний науковий потенціал, здатний цілісно, оперативно та інноваційно розв'язувати нагальні проблеми освітньої сфери, забезпечувати системність і наступність у плануванні та здійсненні наукових досліджень з розвитку освіти, педагогіки і психології.

В іï установах упродовж багатьох десятиліть сформовано відомі наукові школи, високопрофесійний кадровий склад, що системно науково і методично забезпечує всі рівні й ланки освіти, ефективну реалізацію її основних функцій впродовж людського життя.

2. НАПН України відзначається, з одного боку, міждисциплінарністю (вчені представляють різні галузі знань і спеціальності - педагогіку, психологію, філософію, економіку, менеджмент, інформаційні технології), з іншого - наявністю наукових установ практично з кожної освітньої ланки, які $€$ єдиними в Україні осередками, де сконцентровано висококваліфікований науковий персонал. Це дає змогу комплексно здійснювати модернізацію освітнього процесу на всіх його рівнях та забезпечувати відповідний психологіч ний супровід. Окремі дослідження можуть виконуватися іншими науковими колективами, зокрема університетами. Проте жоден з них не спроможний провести дослідження, яке цілісно вивчає проблему і знаходить адекватні шляхи їі розв'язання.

3. Крім того, НАПН України $є$ важливим роботодавцем у сфері наукової і науковотехнічної діяльності, що підтримує від занепаду і без того мінімізований науковий потенціал України, зберігає від подальшого зменшення і нині замалу кількість дослідників серед працюючих. Відновлення в контексті інноваційного типу прогресу необґрунтовано зруйнованого наукового потенціалу у сфері освіти потребуватиме багатьох десятирічь напруженої роботи з його відродження.

Цього року колективу НАПН України особливу увагу слід звернути на виконання указів Президента України щодо реалізацій цілей сталого розвитку, розвитку загальної середньої, професійної (професійно-технічної), вищої освіти, а також Національної економічної стратегії на період до 2030 року, затвердженої в березні цього року урядовою постановою. У зв'язку з цим перед НАПН України постають наступні завдання щодо створення в Україні інклюзивного, інноваційного та освіченого суспільства, у якому громадяни мають рівні права і можливості для розвитку своїх здібностей і талантів впродовж життя від народження, насамперед і головним чином у сфері освіти.

\section{У сорері дошкільної освіти:}

- реалізація Концепції освіти дітей раннього і дошкільного віку, розробленої за провідної участі вчених НАПН України, та опрацювання проєкту нового Закону України «Про освіту дітей раннього та дошкільного віку»;

- оновлення змісту і методів відповідно до нової редакції Базового компонента дошкільної 
освіти (державного стандарту дошкільної освіти), підготовленого під науковим керівництвом членакореспондента НАПН України Т.О. Пироженко і затвердженого МОН України у січні цього року, з урахуванням особливостей цієї освітньої ланки, зокрема специфіки ії цифровізації.

у сорері повної загальної середньої і позашкільної освіти:

- підготовка пропозицій щодо забезпечення гарантій доступності та якості загальної середньої освіти, прав учасників освітнього процесу шляхом актуалізації норм чинного законодавства та його подальшого вдосконалення;

- обґрунтування та впровадження шляхів інноваційного розвитку загальної середньої освіти, формування ключових компетентностей здобувачів освіти, необхідних для їх успішної самореалізації, оцінювання результатів навчання учнів, кадрового супроводу освітнього процесу та професійного розвитку вчителів;

- сприяння взаємодії органів державної влади та органів місцевого самоврядування, підприємств, установ та організацій, закладів освіти з розвитку сучасного та безпечного освітнього середовища, включно із закладами позашкільної освіти;

- оновлення змісту і методів освіти відповідно до нового Державного стандарту базової середньої освіти з особливим акцентом на цифровізацію освіти:

- обґрунтування ефективних шляхів впровадження профільної середньої освіти, зокрема на основі формування відповідної мережі профільних ліцеїв;

- розвиток системи освіти дітей з особливими потребами, насамперед на засадах інклюзивного навчання, а також спеціалізованої (наукової, мистецької, спортивної, військової) освіти для обдарованих учнів;

- всебічна науково-експертна підтримка діяльності Консультативної ради з питань сприяння розвитку системи загальної середньої освіти при Президентові України.

У сорері профресійної (професійно-технічної) mа фрахової передвищої освіти:

- участь у розробленні державної цільової програми розвитку професійної (професійнотехнічної) освіти на період до 2027 року;

- підготовка пропозиції щодо вдосконалення системи професійної (професійно-технічної) освіти України з урахуванням кращих міжнародних стандартів і практик, сучасних та перспективних потреб ринку праці, особливо в частині ство- рення інтегрованих багатопрофільних і багаторівневих укрупнених професійних коледжів;

- модернізація змісту професійної (професійнотехнічної) освіти, зокрема шляхом розроблення нових державних стандартів професійної (професійно-технічної) освіти 3 конкретних професій, впровадження в освітній процес інноваційних технологій і методів навчання, сучасних підручників (посібників) та їх електронних версій, ефективних механізмів проходження виробничого навчання, виробничої практики;

- удосконалення роботи з професійної орієнтації і професійного консультування учнівської молоді щодо реалізації права на якісну та доступну професійну (професійно-технічну) освіту, проведення відповідних тематичних та інформаційних заходів;

- оновлення програм підвищення кваліфікації для викладачів, педагогів професійного навчання, майстрів виробничого навчання закладів професійної (професійно-технічної) освіти;

- активізація міжнародної співпраці вчених НАПН України за проєктами оновленої програми EC Еразмус+, з урахуванням її продовження до 2027 р. для трьох сфер діяльності - освіта, професійний розвиток, молодь і спорт;

- наукове і методичне супроводження проєкту Закону України «Про професійну (професійнотехнічну) освіту»;

- науково-експертна підтримка діяльності Ради з питань розвитку професійної (професійнотехнічної) освіти при Президентові України.

у сфері вищої освіти та освіти дорослих:

- участь у завершальному етапі створення Стратегії розвитку вищої освіти України на 20212031 роки, обґрунтування необхідності вдосконалення мережі закладів вищої освіти, їх укрупнення шляхом об'єднання в регіонах, розвитку лідерських університетів світового класу;

- опрацювання проєкту Закону України «Про освіту дорослих»;

- участь в оновленій програмі Європейського Союзу «Еразмус+» на 2021-2027 рр. і рамковій програмі науково-технічного співробітництва $\in C$ «Горизонт Європа»на 2021-2027 рр.

у сорері психологічного наукового і методичного супроводу освіти, розвитку людини:

- осмислення і розв'язання проблем, зумовлених світовою пандемією COVID-19, що засвідчила кризові явища в багатьох аспектах глобального, національного та особистого існування і розвитку людства, зокрема в Україні, та надання відповідних рекомендацій; 
- здійснення наукових досліджень та розроблення методичних рекомендацій щодо комплексу інших критично небезпечних кризових явищ, яких зазнало українське суспільство, насамперед через російську агресію, дестабілізацію соціальноекономічної ситуації в країні, та обґрунтування практичних заходів щодо подолання викликів і загроз засобами освіти.

\section{У сорері цифрровізації освіти:}

- проведення комплексних досліджень і надання відповідних рекомендацій для цифровізації усіх рівнів і ланок освіти, розвитку цифрових компетентностей здобувачів освіти, вчителів, викладачів та керівників освітніх закладів, впровадження цифрових технологій в освітній процес;

- розгляд цифровізації як незворотної зміни способу освіти, людського життя і розвитку людини.

У рік 30-річчя Незалежності України науковим колективам, членам НАПН України необхідно докласти особливих зусиль з тим, щоб максимально сприяти вирішенню назрілих проблем у суспільному розвитку України, зокрема ії освітньої сфери, забезпечити подальший динамічний прогрес нашої країни. Необхідно повною мірою виконати План заходів НАПН України до 30-річного ювілею Української держави. Особливу увагу потрібно приділити своєчасному завершенню і виданню українською, англійською та німецькою мовами Національної доповіді про стан і перспективи розвитку освіти в Україні (до 30-річчя незалежності України), а також другого видання «Енциклопедії освіти України».

Підготовка Національної доповіді про стан і перспективи розвитку освіти в Україні (до 30-річчя незалежності Украйни) та другого видання «Енциклопедії освіти України

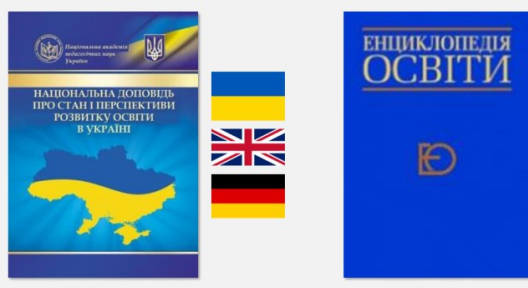

\section{СПИСОК ВИКОРИСТАНИХ ДЖЕРЕЛ}

Електронна бібліотека НАПН України. (n.d.). Головна. https://lib.iitta.gov.ua/

Кремень, В.Г. (2020а). Звіт Національної академії педагогічних наук України про стан використання коштів на наукову і науково-технічну діяльність та отримані результати за 2018-2019 рр. Вісник Національної академії педагогічних наук України, 2(1). https://doi.org/10.37472/2707-305X-2020-2-1-3-5
Кремень, В.Г. (2020b). Про Програму спільної діяльності Національної академії наук України та Національної академії педагогічних наук України на 20202022 роки. Вісник Національної академії педагогічних наук України, 2(1). https://doi.org/10.37472/2707305X-2020-2-1-2-3

Кремень, В.Г. (2021а). Законодавче забезпечення і шляхи реформування Національної академії наук та національних галузевих академій наук. Вісник Національної академії педагогічних наук України, 3(1). https://doi.org/10.37472/2707-305X-2021-3-1-15-1

Кремень, В.Г. (2021b). Партнерський форум «Освіта України 2021: стратегічні цілі та пріоритетні напрями». Вісник Національної академії педагогічних наук України, 3(1). https://doi.org/10.37472/2707305X-2021-3-1-3-1

Кремень, В.Г. (2021с). Про Програму спільної діяльності Міністерства освіти і науки України та Національної академії педагогічних наук України на 20212023 роки. Вісник Національної академії педагогічних наук України, 3(1). https://doi.org/10.37472/2707305X-2021-3-1-11-1

Кремень, В.Г. (ред.). (2021d). Звіт про діяльність Національної академії педагогічних наук України у 2020 p. Київ: НАПН України. https://doi.org/10.37472/ zvit2020

Кремень, В.Г., Луговий, В.І., Топузов, О.М., Регейло, І.Ю., \& Базелюк, Н.В. (2020а). Про виконання Програми спільної діяльності Міністерства освіти і науки України та Національної академії педагогічних наук України на 2017-2020 роки. Вісник Національної академії педагогічних наук України, 2(2). https://doi.org/10.37472/2707-305X-2020-2-2-2-3

Кремень, В.Г., Луговий, В.І., Топузов, О.М., Регейло, І.Ю., \& Базелюк, Н.В. (2020b). Про виконання у 2020 р. Програми спільної діяльності Національної академії наук України та Національної академії педагогічних наук України на 2020-2022 роки. Вісник Національної академії педагогічних наук України, 2(2). https://doi.org/10.37472/2707-305X2020-2-2-2-5

Луговий, В.І., Регейло, І.Ю., \& Гудим, І.М. (2021а). Про результати виконання у 2020 році прикладних наукових досліджень для підтримки молодих вчених. Вісник Національної академії педагогічних наук України, 3(1). https://doi.org/10.37472/2707305X-2021-3-1-2-1

Луговий, В.І., Регейло, І.Ю., \& Гудим, І.М. (2021b). Про співпрацю Національної академії педагогічних наук України з комітетами Верховної Ради України у 2020 р. Вісник Національної академії педагогічних наук України, 3(1). https://doi.org/10.37472/2707305X-2021-3-1-16-2

Наукова продукція Національної академії педагогічних наук України, рекомендована до впровадження (2020р.) : Збірник анотованого переліку наукової продукції. Київ: НАПН України. https:// bit.ly/3eq54d5

Національна академія педагогічних наук України (n.d.). Головна. http://naps.gov.ua/

Національна академія педагогічних наук України. (2021). Інформація Національної академії педагогічних наук України про використання коштів Державного бюджету України за 2020 рік. https://bit.ly/3einBYY 


\section{ON THE NATIONAL ACADEMY OF EDUCATIONAL SCIENCES OF UKRAINE ACTIVITY}

IN 2020 AND THE TASKS FOR 2021

Scientific report at the General Meeting of the National Academy of

Educational Sciences of Ukraine, April 9, 2021

Vasyl Kremen

DSc in Philosophy, Professor, Full Member (Academician) of NAS of Ukraine and NAES of Ukraine, President, National Academy of Educational Sciences of Ukraine, Kyiv, Ukraine

Abstract. The National Academy of Educational Sciences of Ukraine activity in 2020 is presented; it was focused on the theoretical and methodological, scientific and methodical support of the national education system functioning and development, performing statutory tasks in general, according to the priorities of state education policy defined by the strategic and program documents. The results of the academy's, its subordinated institutions, groups of researchers, full members (academicians), and corresponding members' activities are presented. The most important scientific achievements of the academy's researchers according to the results of basic and applied researches with the social effect of their implementation are given. The work of two general meetings and methodological seminars, as well as the Presidium of NAES of Ukraine, are presented. The experimental, publishing, scientific and organizational, scientific and expert, educational, international, scientific and informational activity, collaboration with public authorities and research organizations, the scientific periodicals and researchers' publications representation in the world system of scientific communications, scientific and practical events conduction, as well as financial assurance, are enlightened in detail.

Keywords: National Academy of Educational Sciences of Ukraine; research activities; Ukrainian education; pedagogy; psychology; scientific and methodological support; innovative person.

Дата публікації: 23 квітня 2021 р. 